Article

\title{
The Effects of Customer Perception and Participation in Sustainable Supply Chain Management: A Smartphone Industry Study
}

\author{
Hyunsoo Kim ${ }^{1}$ and Chang Won Lee ${ }^{2, *(1)}$ \\ 1 Center for Technology Business Studies, Hanyang University, Seoul 04763, Korea; \\ hyunsookim@hanyang.ac.kr \\ 2 Division of Business Administration, Hanyang University Business School, Seoul 04763, Korea \\ * Correspondence: leecw@hanyang.ac.kr
}

Received: 30 April 2018; Accepted: 26 June 2018; Published: 2 July 2018

\begin{abstract}
This empirical study aims to identify the relationship between the role of customer and the customer's perception and participation in sustainable supply chain management (SSCM). It also aims to examine the relationships among customer's perception in the SSCM practices, self-brand connection, trust, purchase intention, and the willingness to pay a price premium. Previous studies were reviewed, and statistical analysis was conducted with reliability and validity tests, correlation analysis, and a structural equation model. A smartphone industry was selected and a total of 367 data were utilized for this empirical study. The analysis results showed that the customer's perception of a brand's SSCM has a positive impact on the customer's self-brand connection and trust prospectively. Customer's participation in SSCM also had a positive relation to customer's self-brand connection and to trust. Self-brand connection and trust played mediating roles between the customer's perception and purchase intention and between the customer's perception and the willingness to pay a price premium. The same mediating roles of self-brand connection and trust were found between customers' participation and purchase intention as well as between customers' participation and the willingness to pay a price premium. This study identifies the roles of customers as end users in sustainable supply chain management. This study provides managerial insights about customers' perception of SSCM and their participation in it, resulting in better financial outcomes and improved operational excellence.
\end{abstract}

Keywords: sustainable supply chain management; customer's perception; participation; self-brand connection; trust; purchase intention; willingness to pay a price premium

\section{Introduction}

This study started from the question of whether customers consider the supply chain histories when they decide to buy the product. There is a limit to long-term sustainable supply chain management (SSCM) if the impact on the buyer's product purchase decisions is uncertain, even if companies recognize the importance of SSCM. Regarding corporate social responsibility (CSR) practices, SSCM is an important issue. GAP had been criticized for producing products by exploiting the child labor of developing countries, and Apple had also faced criticism with the problem of labor exploitation of Foxconn. As in these cases, when criticisms are raised about the working environment of workers, customers become aware of the inconsistency between the CSR and SSCM practices. Social sustainability risks in the supply chain, combined with other risk factors, cause big problems for the company and reduce profits [1]. Therefore, CSR is not limited to individual firms but expanded to the entire supply chain [2]. All the more, for companies to gain the competitive advantage in the market, CSR activities should be expanded to all suppliers [3]. Integrating sustainability into 
a company's supply chain management helps firms gain the competitive advantage in the global competitive market [4]. This is because companies can differentiate themselves from other companies through activities such as using natural resources appropriately, paying attention not to destroy the environment, and fulfilling social responsibilities regarding employee health and safety [5]. Also, internal and external pressures on firms' sustainable management are growing, as investors, workers, consumers, and governments require companies to improve their social and environmental responsibility [6]. More and more customers are trying to influence product and service providers through consumption behavior [7]. Consumers perceive ethical consumption as their subjective activity [8], and awareness and consumption of products related to ethical consumption such as fair trade products, environmentally friendly products, social enterprise products, and local foods are increasing. As a result, the ethical market is expanding $[9,10]$. These ethical consumption trends have an important impact on the corporate environment and require firms to produce products and conduct business activities in a way that fulfills social, economic, and environmental responsibilities [11]. However, there is a lack of research on the effects of customer perception and participation on customer behavior in SSCM. This study aims to analyze the effect of customer perception and participation on customer purchase behavior in SSCM and find the mediation variables. It also aims to identify the roles of customers in the supply chain management by linking SSCM and customer participation and to present the direction of customer participation strategy in SSCM. In other words, to analyze the effects of perception and participation of customers on SSCM on product purchase intention and price premium payment intention, empirical studies were conducted to examine perceptions, participation, self-brand connection, purchase intention, and the willingness to pay a price premium.

To achieve the purposes of the study, we have selected the methods of research model setting and verification. First, the necessity and basis of the study were confirmed by reviewing the existing research on the constructs: definition of SSCM, existing research on SSCM, the role of customer participation in supply chain management, self-brand connection, trust, purchase intention, and willingness to pay a price premium. Second, the research model was constructed based on the proposed research question and previous research. The research model is presented to analyze the relationship between the concept of customer perception, customer participation, self-brand connection, trust, purchase intention, willingness to pay a price premium. The empirical study was conducted to verify the research model through data collection and statistical analysis using SPSS and AMOS.

This study is structured as follows. The next section presents a preliminary study on the main constructs. The third section provides the research model, hypothesis, data collection and the fourth offers analysis results. The fifth section presents discussion, implications, and limitation of the study. The final section provides the conclusion.

\section{Literature Review}

\subsection{SSCM}

Gualandris and Kalchschmidt [12] defined SSCM as a new prototype that improves environmental efficiency and social responsibility in the supply chain while meeting stakeholders' needs and improving profitability and competitiveness. Seuring and Müller [6] defined SSCM as management of materials, information, and capital flows across the supply chain, taking all the goals of sustainable development in economic, environmental, and social aspects that arise from the needs of customers. Carter and Rogers [13] defined SSCM as strategically and transparently integrating and achieving the social, environmental, and economic goals of the organization in the systematic synchronization of primary business processes to improve the long-term operational performance in a supply chains stream. Ahi and Searcy [14] noted that SSCM is integrating and coordinating economic, environmental, and social considerations with the major inter-organizational business systems related to the procurement, production, and distribution of goods, information, and capital flows to meet the needs of stakeholders and to improve profitability, competitiveness, and resilience of the organization 
in the long-term. The definitions of SSCM include environmental, social, and economic considerations, which are linked to the objectives of the firm and include coordination and integration of materials, information, and capital flows. Thus, SSCM can be defined as the integration of environmental, social, and economic sustainability and corporate objectives so that stakeholders from the initial supplier to the end user manage the flow of raw materials and products effectively and efficiently.

More and more customers are considering the impact of their purchase behavior on society [15]. $87 \%$ of customers are concerned about the environmental and social impact of the product they purchase [16]. To make decisions about product purchasing, there is an increasing demand from customers who want to know about product sustainability, production history, and supply chain information $[17,18]$. Customers consider environmental knowledge and brand awareness when choosing environmentally friendly products [19-21]. A study on the positive effects of SSCM on customers' purchasing and their financial performance was presented. SSCM has the advantage that customers perceive that the product quality and brand equity are improving due to environmental and social management methods [22]. This leads to financial gains for the company by increasing market share and higher product prices, and purchasing with environmental factors positively affects firm performance regarding net profit and cost of sales [23,24]. Rao and Holt [25] studied the integration of green supply chain management in each stage of supply chain management as environmentally-friendly activity ultimately enhances competitiveness and creates the financial performance. Lee and Woo [26] explored that the eco-friendly supply chain management enhanced corporate performance by promoting sustainable strategic management that simultaneously pursues economic profitability, environmental soundness, and social responsibility.

\subsection{Customer Participation in the SSCM}

Customer participation is the customer's input of effort, time, knowledge, or other types of resources related to service production and delivery [27]. Customer participation can be defined as the act of actively putting various efforts by customers in the use of services [28]. Customer participation in the context of SSCM is defined as 'the customer's injecting of effort, time, knowledge, or other forms of resources into a company's environmental, social, and economic SSCM activities' [29,30]. Research on customer engagement in SSCM is going beyond the customers' role of purchasing sustainable products. According to Ahn and Rho [31], the extent of customer participation has expanded into a social and functional role whereas customer participation was focused regarding customer satisfaction or business interests in the past. An integrated framework involving customer participation motivating factors, customer participation degree determinants, customer participation outcomes, and customer participation management strategies is needed to investigate customer engagement in SSCM practices. In a study that analyzed customers as enablers of SSCM, it was found that customer interests, participation, and expectations played a positive role in enabling companies to implement SSCM [32-34]. Furthermore, Mangla et al. [35] regarded customer perceptions, customer support, and participation as the factors enabling SSCM.

Some research indicates that customers are obstructing the implementation of SSCM. The customers' preference for lower prices is an obstacle for companies to implement SSCM [33,36]. Auh et al. [37] studied whether information flow through communication between customers and firms strengthened the customer-firm relationship and built trust. One of the most effective ways for customers to participate in SSCM is online communities owing to the development of social media and its convenience. In the study of the relationship between SSCM participation and customer's trust, it was found that customers' participation in the online community activity of the brand positively influences the customer's trust [38].

\subsection{Self-Brand Connection}

The self-brand connection refers to the degree to which the customer connects the perceived brand meaning to his or her self-concept [39]. It is a cognitive and emotional link between brand 
and self and reflects the extent to which a customer sees a brand as integrated into their identity [40]. The self is composed of various dimensions and plays a role in achieving various purposes [41]. Among the various dimensions of the self, this study is focused is the altruistic self. The altruistic self is not only concerned with his or her welfare and that of families but also with the well-being of people living in future generations and other countries [11]. When a brand contributes to the achievement of a voluntary motivated goal by the customer, the self and the brand are linked [42].

Previous studies have shown that self-brand connection has a significant impact on consumers' brand evaluations, attitude intensities [39], and behavioral intentions [43]. When customers become aware of the product's SSCM, they become aware that they can help achieve their own altruistic goals and strengthen their self-brand connection compared to products that do not participate in SSCM [44]. The customers want to connect the image of the product with the ideal self that they want to be among the various dimensions of the self [45]. According to Escalas and Bettman [42], self-brand connection affects customer buying behavior. The use of products produced by SSCM is an act of realizing the customer's self. As a result, the intention to purchase products from SSCM through enhanced self-brand connection increases [44]. By linking the social image of the product with the self, the willingness to pay a price premium increases [46,47].

\subsection{Trust}

Trust is defined as a willingness to rely on the other party's actions in a transaction [48]. Trust refers to a state of confidence that the other party is trustworthy, and trust exists when the party has confidence in the integrity and consistency of trust in other parties [49]. Chen [50] developed 'green trust' by combining trust with environmental sustainability. He defined green trust as customers' beliefs that the product will have good results and their willingness to rely on products or services with sustainable characteristics. According to McKnight et al. [51], trust has a significant impact on the customer's ability to overcome perceived risk and determine purchase intention. Studies by Lu et al. [52] and Limbu et al. [53] found that trust has a positive effect on customers' purchase intentions.

Trust plays an important role in determining the intention of customers to purchase products that are produced and sold through sustainable supply management [54]. In the study of Park and Lee [55], corporate social responsibility activities have a positive effect on product trust and trust is found to increase purchase intention.

\subsection{Purchase Intention}

Lee and Son [56] defined purchasing intention as the consumers' willingness to purchase. Engel et al. [57] suggested that the purchase intention is the intention of the customer to perform the purchase in the future and the probability that the belief and attitude are realized as actual purchasing behavior. The theory of reasoned action (TRA) assumes that voluntary actions are determined by their intentions, and individual behavior can be predicted by measuring their intentions [58]. Purchase intention is a point of connection between attitude and actual purchase behavior of the customer, and is also a measure to predict the purchase behavior.

Purchasing behavior can be predicted through purchase intention, but purchase intention does not always lead to purchasing behavior [59]. Unanticipated factors can interfere and change attitudes. However, in business studies predicting purchasing behavior, the method of measuring purchase intention is most often used. In the study on sustainability through supply chain management, studies have identified the factors affecting how customers identify products manufactured through SSCM practices and what makes them either purchase or showing reluctance in doing so [60]. According to Gillespie and Rogers [44], when customers perceive the sustainability component of supply chain management, they reinforce self-brand connection, which leads to purchasing behavior. If a customer recognizes that supply chain management practices hamper sustainability, the purchase intention decreased. In a study by Bonn et al. [61], it is found that environmentally sustainable supply management practice in the wine retail positively influences on customers' purchasing intentions. 


\subsection{Willingness to Pay a Price Premium}

Willingness to pay a price premium for a product or service produced through SSCM is a willingness to pay more than the average price of the same kind of product to purchase the product produced through SSCM practices [62,63]. There is conflicting research as to whether customers are willing to pay higher prices to buy products produced through SSCM. Customers are willing to pay for products produced in a socially conscious manner, such as not experimenting with animals or not using child labor [64]. Customers prefer to pay a significant price premium on products produced in an environmentally sustainable manner [65]. You and Park [66] suggest that consumer knowledge on fair trade coffee has a direct effect on the willingness to pay the price premium. In a study of the range of prices for which customers are willing to pay, De Pelsmacker et al. [62] show that customers are willing to pay about $10 \%$ more for the ethical price premium. The price consumers are willing to pay was found to be at least a $10 \%$ premium and the maximum price premium does not exceed $25 \%$ [67]. A study of eco-labeled apples shows that women who have children and who care about the environment and food safety tend to pay greater price premiums on eco-labeled apples. However, as for the price premium payment amount, if a general apple is 99 cents, was found that the consumer willing to pay 5 cents (5\%), confirming a small price premium payment intention [68].

Loureiro and Lotade [69] indicate that a customer is reluctant to pay a price premium to buy it when a customer has to pay a price premium, even if they perceive the company's product quality, health aspect, and environmental sustainability as ethical. Price-sensitive consumers have higher probability in that they do not pay price premiums for environment-friendly certified items [70]. Hsieh and Chang [71] identifies that the relationship between customer participation and price sensitivity. Customer participation has four forms: preparation, relationship building, information exchange, and intervention. The study suggests that the higher the customer participation, the less sensitivity to the customer's price.

\subsection{SSCM of Smartphone}

Bask et al. [72] categorizes SSCM activities into four frames from the perspective of mobile phone manufacturers: sustainable strategy and policy, sustainable product design, sustainable sourcing, and end of life management. Sustainable strategy and policy include whether the firm has vision, strategies, and policies to pursue sustainability, for example, by adopting life cycle assessment tools or publishing the CSR report [73]. Sustainable product design gives sustainability to the entire supply chain from product and production planning to the end life management. In the product design stage, $80 \%$ of the supply chain cost is determined and affects decomposition, reuse, and recycling [74]. Sustainable sourcing involves environmental activities of suppliers such as recycling, disposal of hazardous materials and waste, assurance of a safe and ethical working environment for suppliers, and the use of certification tools by manufacturers to assess the environmental sustainability of their suppliers [73]. End-of-life management policies include the development of efficient processes for recycling, return, and product recovery. When applied to mobile phones, it involves reuse and recycling, participating in programs aimed at product recycling, reselling recycled products, repairing and upgrading recycled products, and sharing information on materials and parts recycling [72]. Among the four frames of SSCM activities in mobile phones, sustainable product design and end-of-life management has greater possibility of customers' participation. Bask et al. [72] divide the sustainability characteristics of mobile phone supply chain management into five categories based on the areas of interest to customers: physical strength and life of the product; software and hardware updates; mobile phone recycling with plastic and metal parts; hazardous raw materials and waste disposal; and ethical labor and environmental conditions of the supplier. 


\section{Analytical Framework}

\subsection{Hypothesis}

In accordance with the purpose of the study, the hypotheses are set up as presented in Figure 1 about the relationship between customers' perception of SSCM of a product, customers' participation in SSCM, self-brand connection, trust, purchase intention, and willingness to pay a price premium.

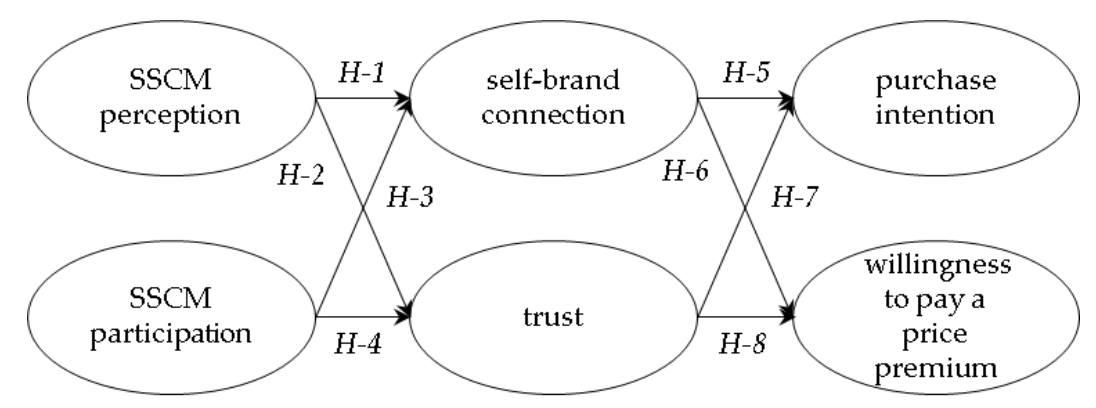

Figure 1. Framework of research model.

According to Keller [45], the self is composed of several dimensions, and the customer wants to express the ideal self that he/she wants to be among the various dimensions of the self by buying the product. When customers become aware of the product's SSCM characteristics they become aware that the product is useful to achieve their goal of expressing their self-esteem. The awareness leads to strengthening self-brand connection [44]. According to Grisaffe and Nguyen [75], if a customer's unique interests such as social or altruistic goals are achieved by the purchase of a product, it becomes a prerequisite to forming an emotional attachment with the brand. In other words, the customer's perception of SSCM characteristics of products can strengthen the emotional attitude of self-brand connection owing to self-achievement resulting from product use and psychological satisfaction due to altruistic behavior. Therefore, this study set the following hypothesis on the relationship between customer's SSCM perception and self-brand connection.

Hypothesis 1 (H1). Customer perception of SSCM practices will have a positive (+) effect on the self-brand connection.

According to Kim et al. [76], customer perceived product value is an important factor in positively affecting product trust. This study was conducted to investigate the effects of SSCM on customers' attitudes, and it has been studied that eco-friendly characteristics of products have a positive effect on customer's trust [54,77]. In the study by Punyatoya [78], it is argued that trust increases when customers perceive the environmentally-friendly characteristics of products. Therefore, based on these previous studies, we hypothesized the relationship between customers' SSCM perception and trust.

Hypothesis 2 (H2). Customers' perception of SSCM practices will have a positive (+) impact on customers' trust.

Consumers are influenced by consumer experience and engagement groups involving brands [79]. Customer participation has been found to improve firm-customer relationships [80-82]. In the process of producing and delivering services, customers are involved in information sharing, responsible behavior, and personal interaction. In this process, interaction with the service provider and customer participation increase [83]. Customer participation has been shown to enrich the interactions between the company and its customers, to have a positive effect on the customer's positive emotions, and to improve customer satisfaction and service quality [84]. Based on the research, Hypothesis 3 on the relationship between customer participation in SSCM practices and the self-brand connection is proposed as follows. 
Hypothesis 3 (H3). Customers' participation in SSCM practices will have a positive (+) effect on customers' self-brand connection.

Mustak et al. [80] categorized customer participation into responsible behaviors, sharing of information and knowledge, and interaction with firms or customers. According to a study [41], information flows through communication between customers and businesses strengthen their relationships with customers and build trust. Thus, customer participation through sharing information and knowledge forms trust with customers. Casaló et al. [38] found that participating in a brand's online community activity positively affects customer trust and that it was one of the most effective ways for customers to participate in SSCM. Therefore, we hypothesized the relationship between customer participation in SSCM practices and trust.

Hypothesis 4 (H4). Customers' participation in SSCM practices will have a positive (+) impact on customers' trust.

The self-brand connection affects customer buying behaviors [42]. Purchasing products produced through SSCM is an act of realizing the customer's self. According to a study by Gillespie and Rogers [44], customers recognize the sustainability component of supply chain management and enhance the self-brand connection, which leads to purchasing behavior. In contrast, on recognizing supply chain management practices that are detrimental to sustainability, cognitive dissonance occurs and reduces purchase intention. Therefore, we hypothesized the relationship between the self-brand connection and purchase intention as follows.

Hypothesis 5 (H5). Customers' self-brand connection will have a positive (+) effect on purchase intention of products produced through sustainable supply management.

Auger et al. [64] stated that customers were willing to pay for purchasing products produced in a socially conscious manner, such as not experimenting with animals or not using child labor. Johnston et al. [65] suggested that customers prefer to pay a significant price premium on products produced in an environmentally sustainable manner. In a study of the range of prices for which there is a willingness to pay, the customer was willing to pay an additional price premium of about $10 \%$ for ethical purchases [62].

Anselmsson et al. [46] and Tikkanen and Vääriskoski [47] have found that linking themselves with brands has a positive role in paying price premiums for these customers. The customer wants to connect the ideal image of the product with the ideal self that wants to be one of the various dimensions of the self. The link between the social image of the product and the self is considered to be a driver of paying a price premium [45]. Therefore, the hypothesis about the relationship between a willingness to pay a price premium for products produced through SSCM practices and the self-brand connection is set as follows.

Hypothesis 6 (H6). Customer's self-brand connection will have a positive (+) impact on the willingness to pay a price premium to purchase a product produced through SSCM practices.

According to McKnight et al. [51], trust has a significant impact on the customer's ability to overcome perceived risk and determine purchase intention. Lu et al. [52] and Limbu et al. [53] also found that customer trust positively influenced purchase intention.

Trust plays an important role in determining the intention of customers to purchase products that are produced and sold through sustainable supply management [54]. In the case of products that have sustainability of supply chain management, such as eco-friendly products, trust is more influential on purchasing intention. In the study of Park and Lee [55], corporate social responsibility activities have a positive effect on product trust and trust are found to increase purchase intention. In this study, we hypothesized that customer trust would have a positive effect on purchase intention. 
Hypothesis 7 (H7). Customers' trust will have a positive (+) impact on the purchase intention of products produced through SSCM practices.

According to a study by Auger et al. [64] and Johnston et al. [65], customers are willing to pay a price premium for products produced in a socially conscious manner or an environmentally sustainable manner. In a study of trust and pricing premiums, Park and Lee [55] studied that customer trust has a positive effect on price premium payment intentions for fair products. Ba and Pavlou [85] also found that there is a linear relationship between seller trust and customer's price premium payment intention. In this study, the relationship between trust and the willingness to pay a price premium is hypothesized as follows.

Hypothesis 8 (H8). Customer trust will have a positive (+) impact on customers' willingness to pay a price premium to purchase products produced through SSCM practices.

Other possible direct relationships between constructs were not included in the hypothesis to improve the parsimony of the model and to satisfy the purpose of the study of finding mediation variables. The definitions of six constructs and measurement question items introduced by prior studies are presented in Table 1 and the questionnaire is presented in Appendix A.

Table 1. Definitions and sources of constructs

\begin{tabular}{|c|c|c|}
\hline Construct & Definition & Source \\
\hline $\begin{array}{l}\text { Customer perception } \\
\text { of SSCM practices }\end{array}$ & $\begin{array}{l}\text { Customers' perception of SSCM practice of a product as management } \\
\text { of materials, information, and capital flows across the supply chain, } \\
\text { considering all the goals of sustainable development in economic, } \\
\text { environmental, and social aspects that arise from the needs of customers. }\end{array}$ & [6] \\
\hline $\begin{array}{l}\text { Customer } \\
\text { participation in } \\
\text { SSCM practices }\end{array}$ & $\begin{array}{l}\text { Customers' injecting of effort, time, knowledge, or other forms of } \\
\text { resources into a company's environmental, social, and economic } \\
\text { SSCM activities. }\end{array}$ & {$[30,33,34]$} \\
\hline $\begin{array}{l}\text { Self-brand } \\
\text { connection }\end{array}$ & $\begin{array}{l}\text { The degree to which the customer connects the perceived brand meaning } \\
\text { to the consumer's self-concept. }\end{array}$ & [43] \\
\hline Trust & A willingness to rely on the other's actions in the transaction. & {$[52]$} \\
\hline Purchase intention & $\begin{array}{l}\text { The intention of the customer to perform the purchase in the future and } \\
\text { the probability that the belief and attitude are realized as actual } \\
\text { purchasing behavior. }\end{array}$ & [61] \\
\hline $\begin{array}{l}\text { Willingness to pay } \\
\text { a price premium }\end{array}$ & $\begin{array}{l}\text { Willingness to pay more than the average amount of the same kind of } \\
\text { product to purchase the product produced through SSCM practices. }\end{array}$ & {$[66,67]$} \\
\hline
\end{tabular}

\subsection{Research Methods}

SPSS 22 and AMOS 18 were used for statistical analysis. The analysis procedure is as follows. First, to analyze the overall characteristics of the sample, demographic characteristics were derived through frequency analysis using SPSS. Second, the reliability and validity of the constructs were verified. The reliability analysis was performed by obtaining Cronbach's alpha to secure the internal consistency between the reliability and the measurement items. The validity was evaluated by average variance extracted (AVE) value. The composite construct reliability (CCR) value was determined and confirmed by factor analysis. Cronbach alpha was calculated by SPSS, and the AVE value and CCR value were analyzed using AMOS. Third, correlation analysis was performed using SPSS to find out the correlation between measurement variables. Fourth, structural equation modeling (SEM) was performed using AMOS to verify the research model.

For the empirical analysis of this study, a smartphone brand was selected as a case study for the following reasons. First, we considered the possibility of designing the customer participation in the SSCM in selecting the product group for the empirical analysis. We selected a smartphone 
considering relatively long product cycle, design possibility of customer participation in the supply chain, the convenience of customer participation design using IT. Second, since smartphones are widely used in various age groups worldwide, it is easy to ensure the suitability of the sample for the research purpose when conducting the questionnaire. Third, there is a growing interest among customers in SSCM, including smartphone manufacturing processes and post-use recycling. Fourth, if the results of this study are applied to the smartphone sector, which has a large industrial scale and a large number of users, it can be expected that the environmental, social, and economic sustainability improvement effects will be great.

\subsection{Data Collection}

The responses to the questionnaire were measured with a 5-point Likert scale ranging from 'strongly disagree' to 'strongly agree'. The questionnaire was distributed to respondents aged 20 years or older who were using smartphones. The demography of the survey respondents is presented in Table 2. The survey was conducted online, and a total of 379 responses were collected. 367 responses were included in the analysis (effective response rate of $96.8 \%$ ), excluding 7 incomplete responses. The structural equation should have a sample of sufficient size to estimate the sample. If the sample size is not sufficient, the estimation error becomes large, so that the coefficient estimate cannot be relied upon. A sample size of 200 is considered the minimum required for conducting SEM [86]. Chou and Bentler [87] argued that 200 is relatively small but reasonable size of the sample. If the reliability of estimated variables is high (Cronbach's alpha $>0.90$ ), a sample size of 50 is stable [88]. There are many type II errors in conclusions unless there is a large sample with high reliability of data [89]. Even though there is no consensus on the absolute minimum size of the sample to perform a SEM, this study satisfies the requirement of the sample size with more than 200 and relatively high reliability of constructs to carry out the next step of the research process.

Table 2. Demographic characteristics of survey respondents

\begin{tabular}{|c|c|c|c|}
\hline Item & Value & No & $\%$ \\
\hline \multirow{2}{*}{ Gender } & male & 175 & 47.7 \\
\hline & female & 192 & 52.3 \\
\hline \multirow{5}{*}{ Age } & $20 \sim 29$ & 22 & 6.0 \\
\hline & 30 39 & 80 & 21.8 \\
\hline & $40 \sim 49$ & 198 & 54.0 \\
\hline & $50 \sim 59$ & 39 & 10.6 \\
\hline & over 60 & 28 & 7.6 \\
\hline \multirow{5}{*}{ Income per month (USD) } & under 1500 & 60 & 16.4 \\
\hline & $1500 \sim 3000$ & 70 & 19.1 \\
\hline & $3000 \sim 4500$ & 91 & 24.8 \\
\hline & $4500 \sim 6000$ & 64 & 17.4 \\
\hline & Over 6000 & 82 & 22.3 \\
\hline \multirow{4}{*}{ Education } & high school & 27 & 7.4 \\
\hline & university & 236 & 64.3 \\
\hline & master's degree & 83 & 22.6 \\
\hline & Ph.D. & 21 & 5.7 \\
\hline \multirow{8}{*}{ Occupation } & unemployed & 69 & 18.8 \\
\hline & public service & 53 & 14.4 \\
\hline & clerical staff & 66 & 18.0 \\
\hline & technician & 4 & 1.1 \\
\hline & service & 21 & 5.7 \\
\hline & self-employed & 22 & 6.0 \\
\hline & professional & 114 & 31.1 \\
\hline & student & 18 & 4.9 \\
\hline
\end{tabular}




\section{Data Analysis}

\subsection{Measurement Test}

We processed the analysis to test the reliability and validity of construct measurement scales. Internal reliability and convergent validity were tested, and the results are presented in Table 3. As a result of analyzing the Cronbach alpha coefficient for each construct, it was found that all the construct values ranged from 0.885 to 0.928 , which confirmed the reliability of the measurement. The two measurement items in the perception on SSCM and three items in the participation in SSCM that increase the Cronbach alpha coefficient at the time of removal were removed. If there is a strong correlation between the questions measuring a construct, it can be confirmed that an accurate measurement tool is used to measure the construct. Methods for evaluating convergent validity include a method of evaluating convergent validity through confirmatory factor analysis, a method of calculating average variance extracted (AVE), and a method of evaluating construct reliability (CR). The results of confirmatory factor analysis are shown in Table 3. The convergent validity values of the measurement items are all significant. The AVE value is also above 0.627 in all items and above the general standard of 0.5. As the standard was suggested by Bagozzi and Yi [90], the value of the conceptual reliability (CR) is 0.7 or more, indicating that there is convergent validity.

Table 3. Internal and convergent validity

\begin{tabular}{|c|c|c|c|c|}
\hline \multirow{2}{*}{ Measurement Scales } & \multirow{2}{*}{ Factor Loading } & \multirow{2}{*}{$\begin{array}{c}\begin{array}{c}\text { Internal } \\
\text { Reliability }\end{array} \\
\text { Cronbach } \\
\text { Alpha }\end{array}$} & \multicolumn{2}{|c|}{ Convergent Validity } \\
\hline & & & $\begin{array}{l}\text { Average Variance } \\
\text { Extracted }\end{array}$ & $\begin{array}{l}\text { Composite } \\
\text { Reliability }\end{array}$ \\
\hline Perception of SSCM (PS) & $\begin{array}{l}0.736^{* * *} \\
0.723^{* * *} \\
0.726^{* * *} \\
0.700^{* * *} \\
0.777^{* * *} \\
0.794^{* * *} \\
0.787^{* * *}\end{array}$ & 0.899 & 0.668 & 0.934 \\
\hline Participation in SSCM (PPS) & $\begin{array}{l}0.581^{* * *} \\
0.825^{* * *} \\
0.825^{* * *} \\
0.743^{* * *} \\
0.798^{* * *} \\
0.763^{* * *}\end{array}$ & 0.885 & 0.627 & 0.909 \\
\hline Self-brand connection (SBC) & $\begin{array}{l}0.878^{* * *} \\
0.902^{* * *} \\
0.825^{* * *} \\
0.767^{* * *}\end{array}$ & 0.903 & 0.772 & 0.931 \\
\hline Trust $(\mathrm{T})$ & $\begin{array}{l}0.824^{* * *} \\
0.873^{* * *} \\
0.850^{* * *}\end{array}$ & 0.883 & 0.825 & 0.934 \\
\hline Purchase intention (PI) & $\begin{array}{l}0.881^{* * *} \\
0.908^{* * *} \\
0.853^{* * *} \\
0.859^{* * *}\end{array}$ & 0.928 & 0.818 & 0.947 \\
\hline $\begin{array}{l}\text { Willingness to pay a price } \\
\text { premium (WPP) }\end{array}$ & $\begin{array}{l}0.809^{* * *} \\
0.903^{* * *} \\
0.922^{* * *}\end{array}$ & 0.909 & 0.811 & 0.928 \\
\hline
\end{tabular}


Discriminatory validity represents how well each of the observational variables explains the constructs by examining the extent to which different measurement tools measure different concepts. In this study, the discriminant validity was analyzed by comparing the correlation coefficient with the square root of AVE value of the construct. To confirm the discriminant validity by this method, the correlation coefficient between the constructs should be smaller than the square root of the AVE value. As shown in Table 4, the square roots of the AVE value of all constructs were higher than the correlation coefficient between constructs. The correlation coefficient results also indicate sufficient correlations at the significance level of 0.01 for further analysis as presented in Table 4 .

Table 4. Descriptive analysis and discriminant validity

\begin{tabular}{cccccccccc}
\hline Variables & $\boldsymbol{m}$ & S.D. & $\boldsymbol{V}$ & $\mathbf{1}$ & $\mathbf{2}$ & $\mathbf{3}$ & $\mathbf{4}$ & $\mathbf{5}$ & $\mathbf{6}$ \\
\hline PS & 3.90 & 0.80 & 0.64 & $\mathbf{0 . 8 1 7}$ & & & & & \\
PPS & 3.69 & 0.90 & 0.81 & $0.476^{* * *}$ & $\mathbf{0 . 7 9 2}$ & & & & \\
SBC & 3.68 & 0.85 & 0.72 & $0.619^{* * *}$ & $0.592^{* * *}$ & $\mathbf{0 . 8 7 9}$ & & & \\
T & 3.69 & 0.74 & 0.55 & $0.653^{* * *}$ & $0.472^{* * *}$ & $0.712^{* * *}$ & $\mathbf{0 . 9 0 8}$ & & \\
PI & 3.58 & 0.85 & 0.73 & $0.499^{* * *}$ & $0.620^{* * *}$ & $0.679^{* * *}$ & $0.640^{* * *}$ & $\mathbf{0 . 9 0 4}$ & \\
WPP & 3.11 & 0.90 & 0.81 & $0.434^{* * *}$ & $0.445^{* * *}$ & $0.591^{* * *}$ & $0.518^{* * *}$ & $0.593^{* * *}$ & $\mathbf{0 . 9 0 1}$ \\
\hline
\end{tabular}

Diagonal elements in bold are the square root of AVE. Off-diagonal elements present binary correlations among constructs. Note: ${ }^{* * *} p<0.01$.

\subsection{Hypothesis Test}

Hypothesis 1 is to test the relationship between customer's SSCM perception and self-brand connection. The value of C.R. represents the statistical significance of the path coefficient. If the value is greater than \pm 1.965 or less than 0.05 , it is statistically significant. As a result of the structural model analysis, the standardization coefficient was 0.505 at the significance level of 0.01 and the value of C.R. was 9.376. The results imply that a customer's perception of a company's SSCM activities has a positive impact on the self-brand connection. Thus Hypothesis 1 has been adopted.

All eight hypotheses were adopted as the standardization coefficients were significant at the significant level of 0.01 and the values of C.R were within the significant standard. The results of each hypothesis test are presented in Figure 2 and Table 5.

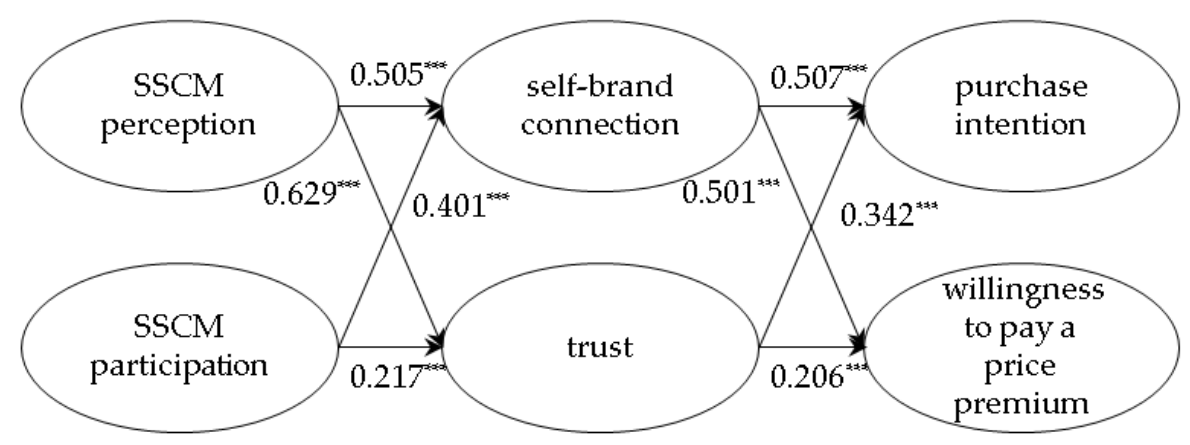

Note. ${ }^{* * *} p>0.01$.

Figure 2. Model summary. 
Table 5. Summary of path analysis

\begin{tabular}{ccccccc}
\hline Hypothesis & Path & B & $\boldsymbol{\beta}$ & S.E. & C.R. & $p$ \\
\hline 1 & PS $\rightarrow$ SBC & 0.540 & 0.505 & 0.058 & 9.376 & 0.000 \\
2 & PS $\rightarrow$ T & 0.639 & 0.629 & 0.063 & 10.082 & 0.000 \\
3 & PPS $\rightarrow$ SBC & 0.386 & 0.401 & 0.050 & 7.693 & 0.000 \\
4 & PPS $\rightarrow$ T & 0.198 & 0.217 & 0.050 & 3.995 & 0.000 \\
5 & SBC $\rightarrow$ PI & 0.559 & 0.507 & 0.073 & 7.612 & 0.000 \\
6 & SBC $\rightarrow$ WPP & 0.522 & 0.501 & 0.079 & 6.590 & 0.000 \\
7 & $\mathrm{~T} \rightarrow$ PI & 0.397 & 0.342 & 0.077 & 5.182 & 0.000 \\
8 & $\mathrm{~T} \rightarrow$ WPP & 0.226 & 0.206 & 0.081 & 2.785 & 0.005 \\
\hline
\end{tabular}

The structural model of this study met the criterion in the model fit. The CMIN value divided by the degree of freedom is considered to be appropriate if it is between 2 and 5 . The CMIN/d.f. value of this study model was found to be within the appropriate range of 2.826. Comparative fit index (CFI) is 0.923, NFI (normed fit index) is 0.886, IFI (incremental fit index) is 0.924 and TLI (Tucker-Lewis index) is 0.914 . The standard of these four model fits is based on 0.90 or higher. All of the above four indexes, excluding NFI, exceed the standard value of 0.90 or higher. NFI is 0.886 , which is not much different from standard 0.90. In general, the RMR (root mean-square residual) should be less than 0.05 , and the fit of this model is 0.049 . Thus, the fit of the research model is secured. The results of the study model fit are presented in Table 6.

Table 6. Model fit summary

\begin{tabular}{ccc}
\hline Model Fit & Recommended Value & Value \\
\hline Chi Square & $\leq 5, \geq 2$ & 890.187 \\
CMIN/d.f. & $\geq 0.90$ & 2.826 \\
CFI & $\geq 0.90$ & 0.923 \\
NFI & $\leq 0.05$ & 0.886 \\
RMR & $\geq 0.90$ & 0.049 \\
IFI & $\geq 0.90$ & 0.924 \\
TLI & 0.914 \\
\hline
\end{tabular}

\section{Discussions, Implications, and Limitations}

The results of Hypothesis 1 indicate that when a customer perceives a product's SSCM, he or she becomes aware that it helps to achieve his or her own altruistic goals in contrast to products that do not implement SSCM. This is similar to the study of Gillespie and Roger [44]. Therefore, companies need to be able to make customer recognize the sustainability characteristics. To this end, the supply chain management stage should be improved in a way that improves the sustainability of the supply chain management of products, and it should provide a variety of information and channels that customers can recognize.

The results of Hypothesis 2 are similar to those of Chen and Chang [54] and Chen et al. [77], in which the eco-friendliness of products has a positive effect on customer's trust. This means that when building a sales strategy based on sustainability, it is important for a company to build trust by making customers recognize the product's SSCM characteristics.

Mustak et al. [80] pointed out that customer participation is a positive performance factor between customers and service providers, and that strengthening self-brand connections through customer participation is also one of the positive results. According to Grisaffe and Nguyen [75], it is a prerequisite for a customer to become attached to the brand in emotional form if a customer's unique interests such as social or altruistic goals are achieved through the purchase of goods or service. In other words if the role of the customer in the SSCM of the product helps to achieve the customer's social and altruistic goal, it strengthens the customer's self-brand connection. Therefore, the company can 
design SSCM to increase the customer's self-brand connection by establishing appropriate customer participation strategy in each supply chain management stage such as SSCM, sustainable vision, strategy, policy establishment, service design, procurement, and production. It is important to establish a strategy to form positive feelings for customers' products by realizing their desire and strengthening self-brand connections.

Customer participation consists of sharing information and knowledge, responsible behavior, and interaction with the company or other customers. The results of Hypothesis 4 are the same as those of Auh et al. [37] that information-sharing through customer-company communication strengthens the relationship with customers and builds trust. In the study of Casaló et al. [38], it was found that customer's participation in online community activities had a positive effect on trust. Online community and social network services (SNS) can be useful platforms to offer customers participation opportunities along with the advance of IT technology.

According to Ba and Pavlou [85], the source of trust is defined as familiarity, value and the calculativeness of the profit and loss caused by the other party's deceit. From the results, the familiarity and value acquired through a customer's participation in SSCM can be the source of trust. Therefore, it is necessary for companies to establish a strategy to actively expand the environmental, economic, and social sustainability through the participation of customers in the supply chain management stage of the product, and to increase the trust. This means expanding the role of the customer as a subject that enables SSCM and does not confine itself to a simple consumer. It is necessary to proactively provide ways of expanding the channel of sharing information and knowledge with customers, providing active online or offline community participation opportunities, expanding interactions with customers or companies, and inducing responsible behavior of customers.

The results of Hypothesis 5 are similar to those of Escalas and Bettman [42] that self-brand connection affects customer buying behaviors and to that of Gillespie and Rogers [44] that suggests when customers recognize the sustainability factor of supply chain management, the road to purchase is connected. The results of Hypothesis 5 show that the effects of self-brand connection, which is the degree to which customers connect self-identity and brand in the SSCM, influence the purchase intention. Therefore, companies should use the self-brand connection as a strategy to increase their purchasing intention by making consumers aware of their efforts to improve environmental, economic, and social sustainability in supply chain management and its result.

The results of Hypothesis 7 show that customer trust has a positive effect on purchase intention as suggested by the prior studies such as [55-57]. In the study of Park and Lee [55], corporate social responsibility activities have a positive effect on product trust, and trust increases purchase intention.

The results of Hypothesis 8 are similar to those of Johnston et al. [65] and De Pelsmacker et al. [62]. Therefore, it should be recognized that for products produced through SSCM practices, customers have a willingness to pay a price premium for ethical purchasing behavior, so that a strategy for extending supply chain management sustainability can lead to financial performance.

This study has the following academic implications. First, this study confirms the positive effect of SSCM on purchase intention by providing an empirical analysis of whether the SSCM activities of the company affect the purchasing intention of the customer. Second, this study can be utilized as a basis for strengthening the role of the customer in view of the SSCM. In addition to existing research that limits the role of customers only in the environmental sustainability areas such as recycling, or in the post-use stage, we expand the customer's role to the entire supply chain management area and also to the social and economic aspects, which shows the possibility of improving sustainability of supply chain management and active participation of customers. Third, it provided a parameter for the effect of the SSCM practices on the purchase intention of the company. Self-brand connection and trust are the parameters that have a significant effect on purchase intention. Fourth, we provided an empirical analysis of the effects of SSCM practices on the willingness to pay the price premium that customers pay for ethical purchases of sustainable products. 
This study provides the following practical implications based on the study results. First, the perception of SSCM practices by customers provides a basis for efforts to improve the sustainability of supply chain management of enterprises by providing empirical studies that SSCM enhance purchase intention. Second, the customers' perception of a company's SSCM practices affects positively on the customers' willingness to pay a price premium. Companies can use these findings in cost management and pricing policies for products. In the past, the supply chain management can explore the possibilities of expanding the role of the customer, which was limited to a part of post-use management stage, to the whole stage. Third, based on the research result that customers participate in the SSCM practices of the company strengthen the intention of purchasing products and the willingness to pay a price premium. Firms can effectively design customer's participation strategies in their SSCM practices. Fourth, we present a smartphone as an empirical study object. It can be applied to customer participation design of another product group by presenting sustainability improvement strategy and customer participation strategy by smartphone's supply chain management stage.

This study has limitations as follows: first, this study has selected empirical studies on a smartphone that are produced by SSCM practices. It is a limitation of this study that the cited smartphone with SSCM characteristics is unfamiliar in Korea. Second, we did not investigate the effect of participation in purchasing intention and the willingness to pay a price premium payment on the awareness of SSCM practices and participation in other product groups. Third, for the sake of parsimony of the research model, we did not include variables such as product quality, design, price, and perceived risk, which are included in smartphone purchasers' purchase intention.

The following research can be developed in the future. First, it would be meaningful to analyze the factors that determine a customer's motivation to participate in SSCM and the degree of customer participation. Second, it is necessary to diversify product categories such as apparel, food, books, and travel products to verify the control effect of each product group. Third, in this study, we confirmed the willingness to pay a price premium paid for ethical purchasing behavior of customers participating in SSCM practices. We need to further investigate the extent to which the customer is willing to pay a price premium and what other factors affect it.

\section{Conclusions}

This study applies statistical analysis to investigate the relationship among customers' perceptions of sustainable supply chain management practices, customers' participation in the SSCM, self-brand connection, trust, intention to purchase, and willingness to pay a price premium. The results indicate that perceiving and participating in a company's sustainable supply chain management practices affects the customer's self-brand connection and trust, which strengthens the customer's intention to purchase the product and the willingness to pay a price premium. Our findings suggest that companies should adopt strategies that enhance customers' perception of its sustainable supply chain management and offer customers adequate opportunities to participate in SSCM practices. The empirical evidence presented in this study will be useful for future research investigating customers' roles in SSCM as well as improving it and designing participation opportunities for customers.

Author Contributions: H.K. and C.W.L. conceived and designed the study model design, development, analyses and interpretations. H.K. collected data and made statistical treatments and C.W.L. revised the manuscript. Both advanced the manuscript.

Funding: No funding sources.

Conflicts of Interest: The authors declare no conflict of interest. 


\section{Appendix A. Questionnaire Items for Constructs Measurement}

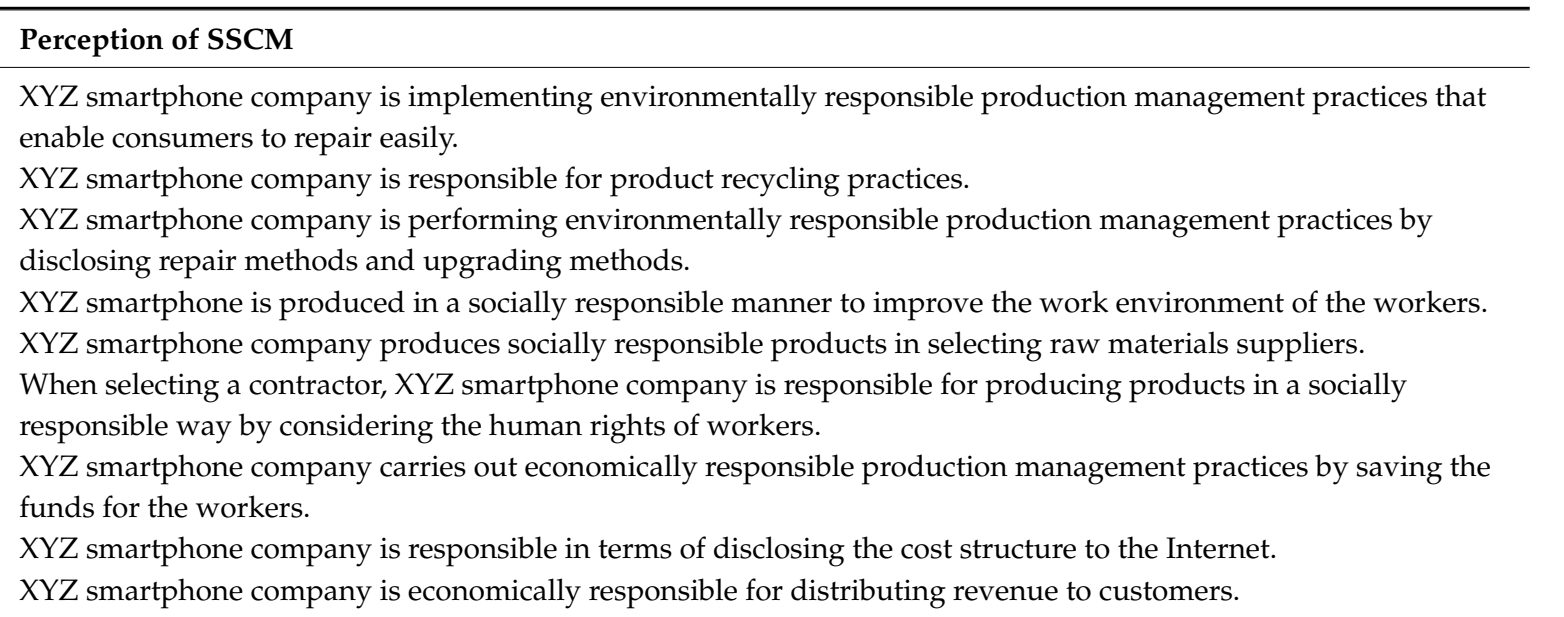

\section{Participation in SSCM}

Since the parts are modular and designed to be easily repaired, I am likely to repair them myself.

I am likely to search for repair guide video since XYZ smartphone company provides it so that customers can repair them themselves.

Since XYZ smartphone company provides open source code for upgrading the software, I am likely to upgrade the smartphone myself.

I will try to find out how and where the raw materials are supplied since the map is available online for customers to search and view.

As XYZ smartphone company provides detailed information, photos, and videos showing the work environment on the webpage, I will search for them and see.

A short online tour program showing the entire production environment of the smartphone is provided, I will participate in it.

I am likely to consider joining the cooperative as XYZ smartphone company distributes the smartphones through the cooperative that distributes the profits to the members.

As XYZ smartphone company provides the information on the price structure on the brand website, I will search for it.

I am likely to receive the information on how the welfare fund for workers is used.

\section{Self-brand connection}

XYZ smartphone company reflects who I am.

The philosophy of the smartphone is consistent with the value I value.

I can explain the smartphone as an example to explain who I am to others.

I think that using the smartphone reflects who I want to be and who I want to show to others.

\section{Trust}

I trust XYZ smartphone company's efforts and commitments for sustainable practices.

$X Y Z$ smartphone company is reliable.

XYZ smartphone company has standards regarding honesty and morality.

\section{Purchase intention}

I am likely to buy XYZ smartphone if I need to buy a smartphone.

When I visit a store to buy a smartphone, I will buy $X Y Z$ smartphone if there is.

I am likely to look for $X Y Z$ smartphone in the store if I buy a smartphone.

I am likely to recommend XYZ smartphone to my friends.

\section{Willingness to pay a price premium}

Even if it is a little more expensive, buying XYZ smartphone is a good thing.

I am willing to pay more than other phones to buy XYZ smartphone.

I will buy XYZ smartphone even if the other smartphones drop the price. 


\section{References}

1. Moon, J.H.; Lee, Y.H. A Framework and research directions for sustainable supply chain risk management. Korean Inst. Ind. Eng. Spring Conf. Proc. 2010, 1499-1506.

2. Andersen, M.; Skjoett-Larsen, T. Corporate social responsibility in global supply chains. Supply Chain Manag. 2009, 14, 75-86. [CrossRef]

3. Lee, K.-H.; Kim, J.-W. Current status of CSR in the realm of supply management: The rise of the Korean electronics industry. Supply Chain Manag. 2009, 14, 138-148. [CrossRef]

4. Faisal, M.N.; Akhtar, A. Sustainable supply chains: 3BL and QFD approach. SCMS J. Indian Manag. 2011, 8, 31-42.

5. Khodakarami, M.; Shabani, A.; Farzipoor Saen, R.; Azadi, M. Developing distinctive two-stage data envelopment analysis models: An application in evaluating the sustainability of supply chain management. Measurement 2015, 70, 62-74. [CrossRef]

6. Seuring, S.; Müller, M. From a literature review to a conceptual framework for SSCM. J. Clean. Prod. 2008, 16, 1699-1710. [CrossRef]

7. Shaw, D.; Newholm, T.; Dickinson, R. Consumption as voting: An exploration of consumer empowerment. Eur. J. Market. 2006, 40, 1049-1067. [CrossRef]

8. Lee, E.M.; Yoon, S.J.; Mun, J.H. The role of socio-psychological characteristics of ethical consumers: Focused on customer citizenship behavior. J. Consum. Cult. 2015, 18, 77-92.

9. Ok, J.W. Relationship between consumer self-determined psychological needs and brand equity for fair trade products. Manag. Inf. Syst. Rev. 2017, 36, 59-79.

10. Park, M.H.; Kang, L.J. Study on the concept and practice of ethical consumption. Korean J. Hum. Ecol. 2009, 18, 1047-1062. [CrossRef]

11. Huh, E.J. The determinants of consumer's attitude and purchase intention on the ethical products. J. Consum. Stud. 2011, 22, 89-111.

12. Gualandris, J.; Kalchschmidt, M. Customer pressure and innovativeness: Their role in SSCM. J. Purchas. Supply Manag. 2014, 20, 92-103. [CrossRef]

13. Carter, C.R.; Rogers, D.S. A framework of SSCM: Moving toward new theory. Int. J. Phys. Distrib. Logist. Manag. 2008, 38, 360-387. [CrossRef]

14. Ahi, P.; Searcy, C. A comparative literature analysis of definitions for green and SSCM. J. Clean. Prod. 2013, 52, 329-341. [CrossRef]

15. Diamantopoulos, A.; Schlegelmilch, B.B.; Sinkovics, R.R.; Bohlen, G.M. Can socio-demographics still play a role in profiling green consumers? A review of the evidence and an empirical investigation. J. Bus. Res. 2003, 56, 465-480. [CrossRef]

16. Bonini, S.M.; Hintz, G.; Mendonca, L.T. Addressing consumer concerns about climate change. McKinsey Q. 2008, 2, 52.

17. Grunert, K.G.; Hieke, S.; Wills, J. Sustainability labels on food products: Consumer motivation, understanding and use. Food Policy 2014, 44, 177-189. [CrossRef]

18. Marucheck, A.; Greis, N.; Mena, C.; Cai, L. Product safety and security in the global supply chain: Issues, challenges and research opportunities. J. Oper. Manag. 2011, 29, 707-720. [CrossRef]

19. Matthes, J.; Wonneberger, A.; Schmuck, D. Consumers' green involvement and the persuasive effects of emotional versus functional ads. J. Bus. Res. 2014, 67, 1885-1893. [CrossRef]

20. Zhao, H.H.; Gao, Q.; Wu, Y.P.; Wang, Y.; Zhu, X.D. What affects green consumer behavior in China? A case study from Qingdao. J. Clean. Prod. 2014, 63, 143-151. [CrossRef]

21. Barber, N. “Green" wine packaging: Targeting environmental consumers. Int. J. Wine Bus. Res. 2010, 22, 423-444. [CrossRef]

22. Mollenkopf, D.; Stolze, H.; Tate, W.L.; Ueltschy, M. Green, lean, and global supply chains. Int. J. Phys. Distrib. Logist. Manag. 2010, 40, 14-41. [CrossRef]

23. Sprinkle, G.B.; Maines, L.A. The benefits and costs of corporate social responsibility. Bus. Horiz. 2010, 53, 445-453. [CrossRef]

24. Carter, C.R.; Kale, R.; Grimm, C.M. Environmental purchasing and firm performance: An empirical investigation. Transp. Res. Part E 2000, 36, 219-228. [CrossRef] 
25. Rao, P.; Holt, D. Do green supply chains lead to competitiveness and economic performance? Int. J. Oper. Prod. Manag. 2005, 25, 898-916. [CrossRef]

26. Lee, Y.K.; Woo, M.J. An empirical study on the effect of supply chain environmental management on corporate performance. Korea Logist. Rev. 2010, 20, 99-125.

27. Dong, B.; Sivakumar, K.; Evans, K.R.; Zou, S. Effect of customer participation on service outcomes: The moderating role of participation readiness. J. Serv. Res. 2015, 18, 160-176. [CrossRef]

28. Yoon, M.H.; Kim, J.S.; Kim, J.H. Effects of personal values and service encounter characteristics on customer participation behavior. J. Market. Manag. Res. 2005, 10, 139-163.

29. Sigala, M. Customer involvement in SSCM: A research framework and implications in tourism. Cornell Hosp. Q. 2014, 55, 76-88. [CrossRef]

30. Sarkis, J. A strategic decision framework for green supply chain management. J. Clean. Prod. 2003, 11, 397-409. [CrossRef]

31. Ahn, J.; Rho, T. Influence of customer-firm relationships on customer participation in the service industry. Serv. Bus. 2016, 10, 113-133. [CrossRef]

32. Faisal, M.N. Sustainable supply chains: A study of interaction among the enablers. Bus. Process Manag. J. 2010, 16, 508-529. [CrossRef]

33. Walker, H.; Jones, N. SSCM across the UK private sector. Supply Chain Manag. 2012, 17, 15-28. [CrossRef]

34. Chkanikova, O.; Mont, O. Corporate supply chain responsibility: Drivers and barriers for sustainable food retailing. Corp. Soc. Responsib. Environ. Manag. 2015, 22, 65-82. [CrossRef]

35. Mangla, S.K.; Govindan, K.; Luthra, S. Critical success factors for reverse logistics in Indian industries: A structural model. J. Clean. Prod. 2016, 129, 608-621. [CrossRef]

36. Orsato, R.J. Competitive environmental strategies: When does it pay to be green? CA Manag. Rev. 2006, 48, 127-143.

37. Auh, S.; Bell, S.J.; McLeod, C.S.; Shih, E. Co-production and customer loyalty in financial services. J. Retail. 2007, 83, 359-370. [CrossRef]

38. Casaló, L.; Flavián, C.; Guinalíu, M. The impact of participation in virtual brand communities on consumer trust and loyalty: The case of free software. Online Inf. Rev. 2007, 31, 775-792. [CrossRef]

39. Moore, D.J.; Miles, H.P. Self-brand connections: The role of attitude strength and autobiographical memory primes. J. Bus. Res. 2008, 61, 707-714. [CrossRef]

40. Chaplin, L.N.; Roedder John, D. The development of self-brand connections in children and adolescents. J. Consum. Res. 2005, 32, 119-129. [CrossRef]

41. Schenk, C.T.; Holman, R.H. A sociological approach to brand choice: The concept of situational self-image. Adv. Consum. Res. 1980, 7, 610-614.

42. Escalas, J.E.; Bettman, J.R. Self-construal, reference groups, and brand meaning. J. Consum. Res. 2005, 32, 378-389. [CrossRef]

43. Escalas, J.E. Narrative processing: Building consumer connections to brands. J. Consum. Psychol. 2004, 14, 168-180.

44. Gillespie, B.; Rogers, M.M. SSCM and the End User: Understanding the Impact of Socially and Environmentally Responsible Firm Behaviors on Consumers' Brand Evaluations and Purchase Intentions. J. Market. Channels 2016, 23, 34-46. [CrossRef]

45. Keller, K.L. Building customer-based brand equity: A blueprint for creating strong brands. Market. Manag. 2001, 10, 14-19.

46. Anselmsson, J.; Johansson, U.; Persson, N. Understanding price premium for grocery products: A conceptual model of customer-based brand equity. J. Prod. Brand Manag. 2007, 16, 401-414. [CrossRef]

47. Tikkanen, I.; Vääriskoski, M. Attributes and benefits of branded bread: Case Artesaani. Br. Food J. 2010, 112, 1033-1043. [CrossRef]

48. Moorman, C.; Deshpande, R.; Zaltman, G. Factors affecting trust in market research relationships. J. Market. 1993, 57, 81-101. [CrossRef]

49. Morgan, R.M.; Hunt, S.D. The commitment-trust theory of relationship marketing. J. Market. 1994, 58, $20-38$. [CrossRef]

50. Chen, Y.S. The drivers of green brand equity: Green brand image, green satisfaction, and green trust. J. Bus. Ethics 2010, 93, 307-319. [CrossRef] 
51. McKnight, D.H.; Choudhury, V.; Kacmar, C. Developing and validating trust measures for e-commerce: An integrative typology. Inf. Syst. Res. 2002, 13, 334-359. [CrossRef]

52. Lu, Y.; Zhao, L.; Wang, B. From virtual community members to C2C e-commerce buyers: Trust in virtual communities and its effect on consumers' purchase intention. Electron. Commer. Res. Appl. 2010, 9, 346-360. [CrossRef]

53. Limbu, Y.B.; Wolf, M.; Lunsford, D. Perceived ethics of online retailers and consumer behavioral intentions: The mediating roles of trust and attitude. J. Res. Interact. Market. 2012, 6, 133-154. [CrossRef]

54. Chen, Y.S.; Chang, C.H. Enhance green purchase intentions: The role of green perceived value, green perceived risk, and green trust. J. Bus. Ethics 2012, 50, 502-520. [CrossRef]

55. Park, H.-J.; Lee, S.-H. Relationship among Corporate Social Responsibility, Trust in Fair Trade Certified Products, Purchase Intention and Willingness to Pay a Premium Price. J. Prod. Res. 2012, 30, 103-122.

56. Lee, J.; Son, J. The Structural Relationship between CSR, Trust, Customer Loyalty, and Purchase Intention as Perceived by Consumer: Mediating Roles of Trust. J. Consum. Cult. 2015, 18, 67-84.

57. Engel, J.F.; Blackwell, R.D.; Miniard, P.W. Consumer Behavior, 8th ed.; Dryder: New York, NY, USA, 1995.

58. Becker, E.A.; Gibson, C.C. Fishbein and Ajzen's theory of reasoned action: Accurate prediction of behavioral intentions for enrolling in distance education courses. Adult Educ. Q. 1998, 49, 43-55. [CrossRef]

59. Sun, B.; Morwitz, V.G. Stated intentions and purchase behavior: A unified model. Int. J. Res. Market. 2010, 27, 356-366. [CrossRef]

60. Young, W.; Hwang, K.; McDonald, S.; Oates, C.J. Sustainable consumption: Green consumer behavior when purchasing products. Sustain. Dev. 2010, 18, 20-31. [CrossRef]

61. Bonn, M.A.; Cronin, J.J.; Cho, M. Do environmental sustainable practices of organic wine suppliers affect consumers' behavioral intentions? The moderating role of trust. Cornell Hosp. Q. 2016, 57, 21-37. [CrossRef]

62. De Pelsmacker, P.; Driesen, L.; Rayp, G. Do consumers care about ethics? Willingness to pay for Fair-Trade Coffee. J. Consum. Affairs 2005, 39, 363-385. [CrossRef]

63. Castaldo, S.; Perrini, F.; Misani, N.; Tencati, A. The missing link between corporate social responsibility and consumer trust: The case of fair trade products. J. Bus. Ethics 2009, 84, 1-15. [CrossRef]

64. Auger, P.; Devinney, T.M.; Louviere, J.J.; Burke, P.F. Do social product features have value to consumers? Int. J. Res. Market. 2008, 25, 183-191. [CrossRef]

65. Johnston, R.J.; Wessells, C.R.; Donath, H.; Asche, F. Measuring consumer preferences for eco-labeled seafood: An international comparison. Am. J. Agric. Econ. 2001, 26, 20-39.

66. You, S.Y.; Park, J. Study of willingness to pay premium and purchasing cost of an ethical product with considering the treatment effect of consumer knowledge. Korean J. Community Living Sci. 2012, 23, 291-305. [CrossRef]

67. Aguilar, F.X.; Vlosky, R.P. Consumer willingness to pay price premiums for environmentally certified wood products in the US. For. Policy Econ. 2007, 9, 1100-1112. [CrossRef]

68. Loureiro, M.L.; McCluskey, J.J.; Mittelhammer, R.C. Will consumers pay a premium for eco-labeled apples? J. Consum. Affairs 2002, 36, 203-219. [CrossRef]

69. Loureiro, M.L.; Lotade, J. Do fair trade and eco-labels in coffee wake up the consumer conscience? Ecol. Econ. 2005, 53, 129-138. [CrossRef]

70. Wang, L.; Huo, X. Willingness-to-pay price premiums for certified fruits-A case of fresh apples in China. Food Control 2016, 64, 240-246. [CrossRef]

71. Hsieh, A.T.; Chang, E.T. The effect of consumer participation on price sensitivity. J. Consum. Affairs 2004, 38, 282-296. [CrossRef]

72. Bask, A.; Halme, M.; Kallio, M.; Kuula, M. Consumer preferences for sustainability and their impact on supply chain management. Int. J. Phys. Distrib. Logist. Manag. 2013, 43, 380-406. [CrossRef]

73. Hervani, A.A.; Helms, M.M.; Sarkis, J. Performance measurement for green supply chain management. Benchmarking 2005, 12, 330-353. [CrossRef]

74. Carter, C.R.; Ellram, L.M. Reverse logistics: A review of the literature and framework for future investigation. J. Bus. Logist. 1998, 19, 85-102.

75. Grisaffe, D.B.; Nguyen, H.P. Antecedents of emotional attachment to brands. J. Bus. Res. 2011, 64, $1052-1059$. [CrossRef]

76. Kim, D.J.; Ferrin, D.L.; Rao, H.R. Trust-based consumer decision-making model in electronic commerce: The role of trust, perceived risk, and their antecedents. Decis. Support Syst. 2008, 44, 544-564. [CrossRef] 
77. Chen, Y.S.; Lin, C.Y.; Weng, C.S. The influence of environmental friendliness on green trust: The mediation effects of green satisfaction and green perceived quality. Sustainability 2015, 7, 10135-10152. [CrossRef]

78. Punyatoya, P. Linking environmental awareness and perceived brand eco-friendliness to brand trust and purchase intention. Glob. Bus. Rev. 2014, 15, 279-289. [CrossRef]

79. Escalas, J.E.; Bettman, J.R. You are what they eat: The influence of reference groups on consumer connections to brands. J. Consum. Psychol. 2003, 13, 339-458. [CrossRef]

80. Mustak, M.; Jaakkola, E.; Halinen, A.; Kaartemo, V. Customer participation management: Developing a comprehensive framework and a research agenda. J. Serv. Manag. 2016, 27, 250-275. [CrossRef]

81. Troye, S.V.; Supphellen, M. Consumer participation in coproduction: "I made it myself" effects on consumers' sensory perceptions and evaluations of outcome and input product. J. Market. 2012, 76, 33-46. [CrossRef]

82. Dabholkar, P.A.; Sheng, X. Consumer participation in using online recommendation agents: Effects on satisfaction, trust, and purchase intentions. Serv. Ind. J. 2012, 32, 1433-1449. [CrossRef]

83. Ennew, C.T.; Binks, M.R. Impact of participative service relationships on quality, satisfaction and retention: An exploratory study. J. Bus. Res. 1999, 46, 121-132. [CrossRef]

84. Suh, M.S.; Ahn, J.W.; Rho, T.S. A study on the voluntary determinants of customer participation and effects on service quality in service encounter-Focused on self-determination theory. J. Consum. Cult. 2010, 13, 61-93.

85. Ba, S.; Pavlou, P.A. Evidence of the effect of trust building technology in electronic markets: Price premiums and buyer behavior. MIS Q. 2002, 26, 243-268. [CrossRef]

86. Boomsma, A.; Hoogland, J.J. The robustness of LISREL modeling revisited. In Structural Equation Models: Present and Future. A Festschrift in Honor of Karl Jöreskog; Cudeck, R., Du Toit, S., Sörbom, D., Eds.; Scientific Software International: Lincolnwood, IL, USA, 2001; Volume 2, pp. 139-168.

87. Chou, C.-P.; Bentler, P.M. Estimates and tests in structural equation modeling. In Structural Equation Modeling: Issues and Application; Hoyle, R.H., Ed.; SAGE Publications: Newbury, CA, USA, 1995; pp. 37-55.

88. Hoyle, R.H.; Kenny, D.A. Sample size reliability and tests of statistical mediation. In Statistical Strategies for Small Sample Research; Hoyle, R.H., Ed.; SAGE Publications: Newbury, CA, USA, 1999; pp. 195-222.

89. Grewal, R.; Cote, J.A.; Baumgartner, H. Multicollinearity and measurement error in structural equation models: Implications for theory testing. Market. Sci. 2004, 23, 519-529. [CrossRef]

90. Bagozzi, R.P.; Yi, Y. On the evaluation of structural equation models. J. Acad. Market. Sci. 1988, 16, 74-94. [CrossRef]

(C) 2018 by the authors. Licensee MDPI, Basel, Switzerland. This article is an open access article distributed under the terms and conditions of the Creative Commons Attribution (CC BY) license (http:/ / creativecommons.org/licenses/by/4.0/). 